Artikel Riset

DOI : 10.33751 /jf.v9i2.1606
Fitofarmaka Jurnal Ilmiah Farmasi

Vol.9, No.2, Desember 2019 : 131-137

p-ISSN : 2087-9164 e-ISSN : 2622-755X

\title{
PENGARUH EDUKASI GIZI DAN PEMBERIAN TABLET TAMBAH \\ DARAH (TTD) TERHADAP KENAIKAN KADAR HEMOGLOBIN REMAJA PUTRI \\ Cantika Zaddana ${ }^{{ }^{*}}$, Lusi Indriani ${ }^{2}$, Naufal Muharam Nurdin ${ }^{3}$, Mutiara Oktavia Sembiring ${ }^{4}$ ${ }^{1,2,4}$ Program Studi Farmasi FMIPA UNPAK, PO Box 452 Bogor 16143 \\ West Java, Indonesia \\ ${ }^{3}$ Departemen Gizi Masyarakat FEMA IPB \\ *E-mail: cantikazaddana@gmail.co.id
}

\begin{abstract}
ABSTRAK
Anemia adalah adalah suatu kondisi yang ditandai dengan penurunan jumlah hemoglobin. Sampai saat ini kejadian anemia pada remaja masih cukup tinggi. Dampak anemia pada remaja antara lain terganggunya pertumbuhan dan perkembangan, kelelahan, tubuh lebih rentan terhadap infeksi, mengurangi kemampuan fisik dan kemampuan akademik Penanganan anemia dapat dilakukan dengan edukasi dan suplementasi tablet tambah darah. Penelitian ini bertujuan untuk menganalisis pengaruh edukasi tentang anemia dan pemberian suplementasi TTD terhadap kadar $\mathrm{Hb}$ pada remaja putri. Faktor-faktor lain yang berkaitan dengan kejadian anemia juga dianalisis seperti pola konsumsi, aktivitas fisik, dan tingkat stress. Hasil penelitian menunjukkan bahwa terdapat kenaikan skor pengetahuan responden setelah diberikan edukasi gizi. Kadar $\mathrm{Hb}$ responden juga mengalami peningkatan setelah diberikan edukasi gizi dan suplementasi TTD.
\end{abstract}

Kata kunci : Anemia, Edukasi gizi, Hemoglobin, Remaja putri, Konsumsi pangan, Zat gizi

\section{EFFECT OF NUTRITION EDUCATION AND IRON SUPPLEMENT ATION ON HB LEVELS IN ADOLESCENT GIRLS}

\begin{abstract}
Anemia is a condition characterized by a decrease in the amount of hemoglobin. The incidence of anemia in adolescents is still quite high. The effects of anemia in adolescents include disruption of growth and development, fatigue, more susceptible to infection, reducing physical abilities, and academic performance. These conditions can be prevented if teenagers have good knowledge about anemia and its prevention. Management of anemia be increase by supplementation of blood builder tablet. This study was aimed to analyze the effect of education and iron supplementation on $\mathrm{Hb}$ levels in adolescent girls. Other factors related to the incidence of anemia such as consumption patterns, physical activity, and stress levels were also analyzed. The results showed that the respondents knowledge scores and $\mathrm{Hb}$ levels was increase after being educate about health and nutrition and iron supplementation.
\end{abstract}


Keywords : Anemia, Nutrition education, Hemoglobin, Adolescent girls, Food consumption, Nutrition.

\section{PENDAHULUAN Latar Belakang}

Anemia adalah suatu kondisi dimana jumlah sel darah merah tidak mencukupi kebutuhan fisiologis tubuh yang ditandai dengan rendahnya kadar hemoglobin $(\mathrm{Hb})$. Sampai saat ini kejadian anemia pada remaja masih cukup tinggi. Hal tersebut ditunjukkan oleh data Depkes RI (2013) yang menyatakan bahwa prevalensi anemia pada kelompok usia 15-24 tahun adalah $18.4 \%$ yang meningkat dari sebelumnya yaitu hanya 6.9\% (Depkes RI 2008), sedangkan penelitian Briawan, et al., (2008) menunjukkan bahwa prevalensi anemia di Bogor adalah 25.1\%.

Remaja putri merupakan salah satu golongan yang rentan mengalami anemia. Hal tersebut disebabkan oleh meningkatkanya kebutuhan gizi untuk mendukung terjadinya peak growth. Selain itu, remaja putri mengalami menstruasi yang menyebabkan pengeluaran darah dalam jumlah yang banyak sehingga menyebabkan hemoglobin menurun secara drastis. Hemoglobin $(\mathrm{Hb})$ merupakan senyawa pembawa oksigen pada sel darah merah. Kandungan hemoglobin yang rendah dapat beresiko terjadinya anemia (Corwin, 2009).

Dampak anemia pada remaja antara lain terganggunya pertumbuhan dan perkembangan, kelelahan, tubuh lebih rentan terhadap infeksi, mengurangi kemampuan fisik dan kemampuan akademik. Hal tersebut dapat dicegah apabila remaja memiliki pengetahuan yang baik tentang anemia dan pencegahannya, pengetahuan seseorang akan mempengaruhi gaya hidup dan pola konsumsi, menurut penelitian Susanti (2016) menyatakan bahwa pendidikan gizi dapat meningkatkan pengetahuan anemia sebesar 43,3\%. Pendidikan gizi yang diberikan adalah pola konsumsi, tanda dan gejala anemia, dampak anemia dan kebersihan diri. Berdasarkan studi yang dilakukan oleh Permatasari, (2018) pada mahasiswi di Bogor menyatakan bahwa konsumsi lauk hewani pada responden sangat rendah yaitu rata-rata responden mengonsumsi daging sapi, ayam, dan hati kurang dari 3-6 kali per minggu padahal protein hewani merupakan salah satu komponen zat gizi yan $g$ berperan dalam penyerapan zat besi (Almatsier, 2010). Pola konsumsi yang tidak baik juga dapat dipengaruhi oleh tingkat stres. Mahasiswi umumnya sering mengalami stress akibat tekanan dari tugas dan jadwal yang padat. Kesibukan dan tingkat stress yang tinggi kadang membuat mereka menghiraukan konsumsi makanannya sehingga lebih lanjut juga meningkatkan resiko terjadinya anemia yang akan berdampak pada kualitas hidup dan prestasi.

Anemia erat kaitannya dengan kelelahan, dimana kelelahan dapat mengganggu aktivitas fisik. Hal tersebut disebabkan karena penurunan kadar hemoglobin akan menurunkan transport oksigen dan menurunnya kemampuan otot untuk menangkap oksigen sehingga akan menyebabkan akumulasi asam laktat (Almatsier, 2010). Selain berdampak pada kemampuan fisik, anemia juga berpengaruh terhadap performance akademik. Studi yang dilakukan oleh Dumilah \& Sumarmi (2017) menunjukkan bahwa terdapat hubungan 
yang signifikan antara kejadian anemia dan prestasi belajar

Penanganan anemia dapat diberikan suplemen besi atau tablet tambah darah. Pemerintah melalui Kementerian Kesehatan mengadakan program pencegahan anemia dengan subsidi pemberian TTD (Tablet Tambah Darah) yang diperuntukkan bagi remaja putri usia 11-18 tahun yang disalurkan melalui sekolah (Kemenkes, 2016). Program ini tidak mengikutsertakan mahasiswi padahal mahasiswi merupakan salah satu golongan yang rentan mengalami anemia. Oleh karena itu, berdasarkan paparan yang telah dijelaskan maka membuat peneliti tertarik untuk melakukan penelitian mengenai pengaruh edukasi gizi dan pemberian tablet tambah darah terhadap kadar hemoglobin pada mahasiswi.

\section{METODE PENELITIAN}

Desain, Tempat dan Waktu

Desain penelitian ini adalah true experimental study, dengan pendekatan purposive. Penelitian ini dilaksanakan di Universitas Pakuan Bogor dan di tempat tinggal masing-masing responden. Waktu yang dibutuhkan dalam penelitian ini adalah lima bulan yang akan dilakukan pada bulan November 2018 - Maret 2019.

\section{Populasi dan Sampel}

Populasi penelitian ini adalah semua mahasiswi FMIPA Universitas Pakuan, sedangkan sampel penelitian ini diambil secara purposive yaitu mahasiswi FMIPA Universitas Pakuan yang memenuhi kriteria inklusi dan eksklusi. Kriteria inklusi yang ditetapkan yaitu mahasiswi yang berusia 18-21 tahun, mengalami anemia diluar menstruasi (kadar $\mathrm{Hb}<12 \mathrm{~g} / \mathrm{dl}$ ), serta bersedia untuk dijadikan responden sedangkan kriteria eksklusi dalam penelitian ini adalah memiliki riwayat penyakit kronis, pendarahan, alergi, dan sedang mengonsumsi suplemen zat besi, vitamin C, atau B12 selama 4 bulan terakhir.

\section{Penarikan Responden}

Penarikan responden dilakukan dua tahap. Tahap pertama dilakukan skrining kepada mahasiswi FMIPA Universitas Pakuan berdasarkan kriteria inklusi dan eksklusi yang telah ditetapkan. Tahap selanjutnya yaitu setelah didapatkan responden yang memenuhi kriteria inklusi dan eksklusi, responden dibagi menjadi 2 kelompok (dengan jumlah yang sama di setiap kelompoknya) yaitu kelompok kontrol (edukasi dan plasebo) dan kelompok intervensi (edukasi dan tablet tambah darah). Pembagian kelompok tersebut dilakukan secara double blind untuk mencegah terjadinya bias data. Responden mendapatkan intervensi sesuai dengan kategori kelompoknya masing-masing.

\section{Teknik Pengumpulan Data}

Data yang diperoleh adalah data primer dan data sekunder. Data primer meliputi karakteristik responden (umur dan kadar hemoglobin), riwayat menstruasi, riwayat penyakit, kebiasaan makan, aktivitas fisik, tingkat stress, dan pengetahuan anemia. Pengumpulan data ini dilakukan dengan pengisian kuesioner dan pengukuran. Data sekunder yang dikumpulkan adalah nama responden yang diperoleh dari absensi kuliah.

Data karakteristik responden berupa kadar hemoglobin diambil menggunakan instrumen hemometer (Easy Touch), sedangkan data riwayat penyakit dan riwayat menstruasi diperoleh dengan cara wawancara yang dilakukan pada awal penelitian. 
Data kebiasaan makan dari makanan sumber zat besi diperoleh dengan wawancara menggunakan kuesioner FFQ (Food Frequency Questionnare) sehingga diperoleh frekuensi konsumsi makanan sumber zat besi kemudian frekuensi tersebut akan dikategorikan menjadi tidak pernah, jarang, dan sering. Data tingkat kecukupan zat gizi (protein, lemak, zat besi, vitamin C, vitamin B12, asam folat) serta makanan yang termasuk enhancer dan inhibitor zat besi diperoleh menggunakan Recall 2x24 jam yang diukur pada hari biasa dan hari libur. Data asupan dan tingkat kecukupan zat gizi tersebut diperoleh dari analisis data menggunakan instrumen Nutrisurvey 2007.

Data tingkat stress diperoleh melalui pengisisan kuesioner langsung oleh responden yang dipandu oleh peneliti. Kuesioner berisi 30 pertanyaan mengenai keluhan atau gejala yang ditimbulkan akibat stress menggunakan kuesioner DASS (Depression Anxiety Stress Scale) yang dimodifikasi. Hasil pengukuran tingkat stress tersebut selanjutnya dikategorikan menjadi tingkat stress ringan, sedang, dan berat.

Data Aktivitas fisik diperoleh melalui wawancara dan pengisian diari aktivitas fisik $2 \times 24$ jam pada hari biasa dan hari libur. Data tersebut selanjutnya diukur menggunakan rumus PAL (Physical activity level) dan PAR (Physical activity ratio).

Pengetahuan tentang anemia diukur menggunakan kuesioner yang dimodifikasi dari kuesioner Aditian (2009) berisi 10 pertanyaan. Kuesioner telah tervalidasi dan memiliki nilai reliabilitas $\quad 0.798$ selanjutnya pengetahuan tentang anemia dikategorika menjadi rendah, sedang, dan baik berdasarkan skor yang diperoleh.
Pengambilan darah untuk pengukuran kadar hemoglobin akan dilakukan oleh 2 orang dokter yaitu dr. Naufal Muharram Nurdin, M.Si dan dr. Irene. Pengambilan sampel darah dilakukan sebanyak dua kali yaitu saat pre dan post intervensi untuk mengetahui perubahan kadar hemoglobin. Alat yang digunakan adalah hemometer (Nescoß) khusus untuk mengukur kadar hemoglobin.

Edukasi gizi diberikan dengan metode ceramah, diskusi, dan tanya jawab. Materi edukasi diperoleh dari penelitian sebelumnya oleh Susanti (2016) yang dimodifikasi. Materi yang diberikan berupa pengertian, penyebab, gejala dan dampak anemia, kebutuhan zat gizi pada remaja, makanan sumber zat besi baik enhancer dan inhibitor nya, dan pentingnya suplemen penambah darah dalam menanggulangi anemia. Edukasi yang diberikan dilakukan dalam satu ruangan dan waktu yang bersamaan untuk tiap kelompok perlakuan.

Intervensi berupa pemberian tablet tambah darah dilakukan selama 30 hari. Tablet tambah darah yang diberikan adalah Sangobion ${ }^{\circledR}$ yang diminum 1 kali dalam sehari pada pagi hari setelah makan (total 30 tablet/orang). Data kepatuhan konsumsi tablet tambah darah diukur berdasarkan diari kepatuhan dan wawancara, apabila tingkat kepatuhan kurang dari $60 \%$ maka responden dianggap drop out. Pada minggu ke-4 (30 hari setelah intervensi) juga akan diadakan posttest untuk mengukur pengetahuan anemia, tingkat stress, dan aktivitas fisik.

\section{Pengolahan dan Analisis Data}

Data yang akan diperoleh dikumpulkan dan diberi kode tertentu dan dioleh menggunakan Ms. Excel. Data yang diperoleh kemudian akan dianalisis 
menggunakan SPSS 23 yaitu analisis Univariat, Bivariat dan Multivariat. Data yang diperoleh berupa tabel dan gambar untuk memudahkan dalam interpretasi data.

\section{HASIL DAN PEMBAHASAN Kadar Hb}

Berdasarkan hasil penelitian diketahui bahwa umur pertama kali responden mengalami menstruasi (menarche) berkisar antara 12-14 tahun.

Rata-rata umur menarche responden pada kelompok intervensi adalah 12.87 \pm 0.758 tahun. Hal ini sejalan dengan penelitian yang dilakukan oleh Februhartanty et al. (2002), Briawan (2008), Brown (2011), dan Adrianto (2013), yang menyatakan bahwa menarche terjadi pada wanita rata-rata ketika usia 12.4 tahun, kisaran terjadi antara usia 9-17 tahun. Lamanya menstruasi responden berkisar 9.91 \pm 3.886 hari dengan rentang 4-14 hari. Pada penelitian ini sebanyak 12 orang memiliki durasi menstruasi yang lebih panjang dari normal (>8 hari) dan 34 orang memiliki durasi menstruasi yang normal $(\leq 8$ hari). Rata-rata kadar hemoglobin responden pada kelompok kontrol (+) adalah $10.12 \pm 0.50$ dan kelompok intervensi adalah $11.06 \pm 0.58$. Beberapa responden kelompok kontrol (+) mengalami efek samping seperti pusing, mual, sembelit dan lemas sebanyak 6 orang, sedangkan sisanya merasakan manfaat yaitu pusing berkurang, badan lebih bugar, lebih konsentrasi dan nafsu makan meningkat. Hal ini sesuai dengan studi Marudut (2012) yang menyatakan bahwa mual muntah adalah efek samping yang paling sering dialami responden setelah diberikan suplemen besi. Sangobion merupakan salah satu suplemen yang terbukti dapat meningkatkan kadar hemoglobin.

\section{Pengetahuan Anemia}

Skor rata-rata pengetahuan anemia pada kelompok kontrol (+) sebelum di berikan edukasi adalah 69.21 \pm 7.96 , setelah diberikan edukasi rata-rata skor menjadi $85.43 \pm 6.55$. Ratarata skor kelompok intervensi sebelum diberikan edukasi adalah $63.86 \pm 0.58$ dan setelah diberikan edukasi menjadi 86.91 \pm 0.55 .

\section{Aktivitas Fisik}

Aktivitas fisik dalam penelitian ini diukur dengan data yang diperoleh dari daily activity kemudian di kategorikan PAL dan PAR menurut WHO/FAO/UNU (2001). Data aktivitas fisik dan kadar $\mathrm{Hb}$ dikolerasikan untuk melihat adaya hubungan atau tidak. Anemia juga diketahui berhubungan dengan kelelahan. Defisiensi besi berhubungan dengan meningkatnya kelelahan, terutama pada wanita.

Pada kelompok kontrol (+) sebagian besar responden yaitu 16 orang $(70 \%)$ memiliki aktivitas yang ringan, 6 orang $(26 \%)$ memiliki aktivitas sedang, dan hanya 1 orang (4\%) yang memiliki aktivitas berat. Pada kelompok intervensi sebanyak 9 orang (39\%) masuk kategori aktivitas ringan dan 14 orang (61\%) masuk kategori aktivitas sedang. Sedangkan pada kelompok intervensi, sebagian besar responden yaitu 14 orang memiliki aktivitas sedang (61\%) dan sisanya memiliki aktivitas fisik yang ringan $(39 \%)$

Mahasiswi fakultas MIPA Universitas Pakuan cenderung memiliki aktivitas yang ringan-sedang, hanya 1 orang yang masuk kategori aktivitas fisik berat. Kategori aktivitas fisik yang berat adalah berkebun, berlari marathon, 
mencuci dan menyetrika pakaian, menimba air dan aktivitas tersebut sangat jarang dilakukan oleh mahasiswi.

\section{Pola Konsumsi}

Pola konsumsi yang diukur dalam penelitian ini mencangkup tingkat kecukupan gizi dan frekuensi makan yang berkaitan dengan anemia. mayoritas responden baik yang termasuk dalam kelompok kontrol maupun intervensi memiliki tingkat kecukupan $\mathrm{Fe}$, protein, vitamin C, dan vitamin B12 dalam kategori defisit berat. Hal ini menunjukkan bahwa remaja putri kurang memperhatikan konsumsi makannya sehingga berdampak pada rendahnya asupan zat-zat gizi yang dapat meningkatkan kadar $\mathrm{Hb}$.

Kebiasaan makan dinilai dari ratarata frekuensi konsumsi berbagai jenis pangan dalam satuan kali per minggu. Data yang diperoleh adalah data yang berkontribusi terhadap penyerapan zat besi. Faktor pendukung penyerapan zat besi antara lain makanan yang kaya akan vitamin $\mathrm{C}$ dan protein hewani. Hasil studi $\mathrm{Du}$, et al (2000) menyatakan bahwa makanan hewani dan vitamin $\mathrm{C}$ dapat mendukung bioavailabilitas zat besi, karena sayur-sayuran dan buah-buahan bertindak sebagai enhancer. Sementara teh, kacang dan kopi memiliki efek inhibitor terhadap bioavailabilitas zat besi.

Makanan yang dapat meningkatkan penyerapan Fe yang sering dikonsumsi oleh mayoritas responden adalah telur, tempe dan tahu, dan selada, sedangkan makanan yang dapat menurunkan penyerapan $\mathrm{Fe}$ yang sering dikonsumsi adalah sereal, teh, dan kopi. Mahasiswi diduga sering mengonsumsi sereal untuk sarapan karena proses penyiapannya yang mudah. Konsumsi teh yang sering pada responden diduga karena mahasiswi terbiasa mengonsumsi makanan utama bersamaan dengan teh. Hal ini juga berdampak pada penyerapan $\mathrm{Fe}$ pada tubuh sehingga meningkatkan resiko terjadinya anemia.

\section{Tingkat Stres dan Pola Konsumsi}

Asupan gizi yang diamati dalam penelitian ini adalah yang asupan yang berpengaruh terhadap kejadian anemia, antara lain zat besi, protein, vitamin c, vitamin B12, dan energi. Rata-rata responden mengalami tingkat stress sedang sampai stress berat. Kondisi mahasiswi yang rentan mengalami stress karena perkuliahan dan lingkungan kampus diketahui dapat berdampak pada pola konsumsi yang berakibat pada jumlah asupan gizinya.

Dari hasil penelitian diketahui bahwa sebagian besar responden pada kelompok kontrol yang mengalami stress berat memiliki tingkat kecukupan $\mathrm{Fe}$, Vitamin C, dan Vitamin B12 dengan kategori defisit berat. Sama halnya dengan kelompok intervensi, diketahui bahwa mayoritas responden yang memiliki stress berat juga memiliki tingkat kecukupan akan $\mathrm{Fe}$, protein, vitamin $\mathrm{C}$, dan vitamin $\mathrm{B} 12$ dalam kategori deficit

\section{KESIMPULAN}

Studi ini menjukkan bahwa terdapat peningkatan skor pengetahuan tentang anemia responden setelah diberikan edukasi gizi. Selain itu juga diketahui bahwa kadar hemoglobin responden mengalami kenaikan sesudah diberikan edukasi gizi dan tablet tambah darah.

\section{REFERENSI}

Aditian, N. 2009. Faktor-Faktor yang mempengaruhi kejadian anemia gizi remaja putri SMP 133 di 
pulau pramuka kepulauan seribu tahun 2009. Skripsi. Jurusan Kesehatan Masyarakat Universitas Indonesia.

Almatsier, S. 2010. Prinsip Dasar Ilmu Gizi. PT Gramedia Pustaka Utama. Jakarta.

Briawan, D., Hardinsyah, H., Setiawan, B., Marliyati, S.A. \& Muhilal, M. 2008. Efikasi suplemen besimultivitamin untuk perbaikan status besi remaja wanita. Jurnal Gizi Indonesia. 30(1):30-36.

Brown, Z. K. \& Boatman, K. K. 2011. 100 Tanya-Jawab mengenai Kanker Payudara Edisi 3. P.T. Indeks. Jakarta.

Corwin, E.J. 2009. Handbook of Pathophysiology $3^{\text {rd }}$ Ed. Jakarta: EGC.

Departemen Kesehatan R.I. 2008. Riset Kesehatan Dasar Tahun 2008. Kementrian Kesehatana Republik Indonesia. Jakarta.

2013. Riset Kesehatan Dasar Tahun 2013. Kementrian Kesehatana Republik Indonesia. Jakarta.

Du, C., Fang, M., Li, Y., Li, L. \& Wang, X. 2000. Smac, a mitochondrial protein that promotes cytochrome c-dependent caspase activation by eliminating IAP inhibition. Cell. 102(1): 33-42.

Dumilah, P.R.A. \& Sumarmi, S. 2017. Hubungan kejadian anemia dan prestasi belajar siswi di SMP Unggulan Bina Insani. Amerta Nutr. 331-340.

Kemenkes RI. 2016. Pedoman Pencegahan dan Penanggulangan Anemia pada Remaja Putri dan Wanita Usia Subur (WUS). Jakarta: Kemenkes RI.

Marudut, M. 2012. Efikasi bubuk tabur gizi terhadap status zat besi remaja putri di pondok pesantren. Disertasi. Sekolah Pasca Sarjana Institut Pertanian Bogor.

Dumilah, P.R.A. \& Sumarmi, S. 2017. Hubungan kejadian anemia dan prestasi belajar siswi di SMP Unggulan Bina Insani. Amerta Nutr. 331-340.

Susanti, Y. 2016. Pengaruh pemberian suplemen besi terhadap kadar hemoglobin dan tingkat kelelahan pada remaja putri. Tesis. Sekolah Pasca Sarjana Institut Pertanian Bogor. 